\title{
IMPLEMENTATION PROCESS OF STRATEGIC PLANNING AT DISTRICT GENERAL HOSPITAL
}

\author{
Proses Pelaksanaan Rencana Strategis Penyedia Pelayanan Kesehatan \\ di Rumah Sakit Umum Daerah \\ ${ }^{*}$ Fiany Dharyanti ${ }^{1}$, Sutopo Patria Jati ${ }^{2}$, Dodik Tugasworo Pramukarso ${ }^{3}$ \\ ${ }_{1,2}$ Faculty of Public Health, Diponegoro University, Indonesia \\ ${ }^{3}$ Director of HR and Education, General District Hospital of Dr. Kariadi Semarang, Indonesia \\ *Correspondence: dharyanti811@gmail.com
}

\begin{abstract}
Background: A strategic plan is the main reference for management in endeavoring to become better and more developed with regard to customers' needs. A preliminary study of documents was conducted at the District General Hospital of Dr. (H.C.) Ir. Soekarno in Bangka, Belitung Province, which has implemented such a strategic plan. This review revealed that there were gaps between expectations and the implementation of the plan.

Aim: This study aimed to analyze that factors that affect the implementation of a strategic plan, such as communication, resources, disposition, and bureaucratic structure.

Methods: This was a descriptive study using a qualitative approach. Primary data were obtained from in-depth interviews with 10 informants, while secondary data were obtained from document analysis. Data processing and analysis were performed using content analysis. Research was conducted from January 2-31, 2019 at the District General Hospital of Dr. (H.C.) Ir. Soekarno.

Results: Some gaps in the implementation process of the strategic plan were revealed. These included: (1) ineffective communication, (2) resource factors (e.g., lack of quality and quantity of human resources, inadequate information, ineffective utilization of budget), (3) weak disposition of some of the implementers, and (4) an irrelevant and maldjusted bureaucratic structure.

Conclusion: The implementation process of the strategic plan was not appropriate because some of its aspectssuch as communication, resources, disposition, and bureaucratic structure-were not appropriately executed. This study suggests that formulators should represent all elements and that strategic planning should involve both internal and external parties. Monitoring, evaluation, communication, and coordination between stakeholders should also take place. Resources need to be improved, and the hospital needs to develop organizational structure and conduct better disposition guidance for executives and implementers.
\end{abstract}

Keywords: implementation, strategic plan, hospital.

\begin{abstract}
ABSTRAK
Latar Belakang: Rencana strategis merupakan acuan utama manajemen dalam melaksanakan kegiatannya menjadi lebih baik, lebih berkembang serta lebih mengetahui apa yang diinginkan oleh pelanggan. RSUD Dr. (H.C) Ir. Soekarno di Provinsi Bangka Belitung telah memiliki rencana strategis. Hasil studi pendahuluan melalui telaah dokumen diketahui terjadi kesenjangan dalam proses implementasi rencana strategis yaitu ketidaksesuaian antara apa yang disusun dengan kondisi sebenarnya.

Tujuan: Penelitian ini bertujuan untuk menganalisis aspek-aspek yang mempengaruhi implementasi rencana strategis yang meliputi komunikasi, sumber daya, disposisi dan struktur birokrasi.

Metode: Penelitian ini merupakan penelitian deskriptif dengan pendekatan kualitatif. Data primer diperoleh melalui wawancara mendalam terhadap 10 informan sedangkan data sekunder didapat dari analisis dokumen. Proses analisis data dilakukan menggunakan analisis konten. Penelitian ini dilakukan di RSUD Dr. (H.C) Ir. Soekarno. Hasil: Penelitian menunjukkan proses implementasi rencana strategis yang dilakukan terjadi beberapa kesenjangan. Kesenjangannya meliputi (1) komunikasi yang tidak efektif; (2) faktor sumber daya, yaitu : SDM yang kurang secara kualitas dan kuantitas, kurangnya ketersediaan informasi, kurang efektifitas dalam pemanfaatan anggaran; (3) disposisi yang kurang baik dari beberapa implementor; (4) struktur birokrasi yang tidak relevan dan akomodatif.

Kesimpulan: Implementasi rencana strategis belum berjalan dengan baik karena beberapa aspek meliputi komunikasi, sumber daya, disposisi dan struktur birokrasi. Rencana strategis juga perlu disusun dengan melibatkan pihak internal dan eksternal. Monitoring, evaluasi, komunikasi dan koordinasi dalam tim perlu dilakukan. Sumber daya perlu ditingkatkan, serta rumah sakit perlu mengarahkan disposisi bagian eksekutif dan pelaksana dan mengembangkan struktur organisasi.
\end{abstract}

Kata kunci: implementasi, rencana strategis, rumah sakit. 


\section{INTRODUCTION}

A hospital is a public organization that provides healthcare for a community. Even though government-owned hospitals do not seek profit, they must always improve their services following environmental changes that occur either inside or outside. Many studies in recent decades have discussed the importance of public organizations studying strategic planning and thinking (Höglund et al., 2018; Bryson, 2016; Rosenberg, Hansen, and Ferlie, 2016; Pollanen et al., 2017; Bryson, Edwards, and Van Slyke, 2018)

Some changes occur rapidly and are affected by various factors such as stakeholders' different perspectives of hospital about hospital services in Indonesia (Assauri, 2017). A hospital is an expensive healthcare center that provides diagnosis, care, and rehabilitation services. Therefore, strategic planning is necessary to improve and maintain the quality of public health (Jamshidi et al., 2017). Hospitals are complex organizations consisting of various services whose main goal is to provide timely, fair, safe, efficient, and effective patient-centered secondary healthcare supported by evidence-based guidelines. The higher the quality of hospital services, the better the effectiveness and outcomes (e.g., patient satisfaction) are (Ferreira et al., 2018). Strategic management is the correct way to benefit from environmental changes and challenges experienced by hospital managers (Esfahani, Mosadeghrad, and Akbarisari, 2018). Leaders or managers must try to link the strategic planning process to environmental changes and strive to implement it (Dibrell, Craig, and Neubaum, 2014). As a driving force, managers are responsible for the development and improvement of managerial quality and being as flexible and innovative as needed for establishing organizational culture (Suarez, Calvo-Mora, and Roldán, 2016).

The hospital exerts great influence on the efficiency of health services (Peixoto, Musetti, and Mendonça, 2018). Hospital services are sophisticated in terms of their organizational structures and stakeholders, and work constantly as well as present challenges for the strategic management to establish fair organization's goals (Helmig, Hinz, and Ingerfurth, 2014). According to Klag and Langley (2014), strategic planning, when applied in the right way and with appropriate leadership, motivation, and political management, can produce very successful strategies. Strategic planning has a positive relationship with strategic implementation, and is more positive if supported by the involvement of management (Elbanna, Andrews, and Pollanen, 2016).

The Republic of Indonesia has transformed its financial approach from traditional budgeting to performance-based budgeting. The performancebased budgeting approach is necessary for local government units that provide public services by making them as state enterprises as regulated by the Law of the Republic of Indonesia Number 17 of 2003 concerning State Finances. In articles 68 and 69 of the Law of the Republic of Indonesia Number 01 of 2004 concerning State Treasury, a government organization is that whose main tasks and functions are the provision of public services that can implement flexible financial management patterns by emphasizing productivity, efficiency, and effectiveness.

To follow up with the laws mentioned above, the Minister of Home Affairs had issued the Law of the Minister of Home Affairs Number 61 of 2007, updating it more recently with Number 79 of 2018 concerning Technical Guidelines for the Financial Management of the Local Public Service Agency, or Badan Layanan Umum Daerah (BLUD). In accordance with these laws, the Regional Government's Working Unit, or Satuan Kerja Perangkat Daerah (SKPD)—which implements the financial management pattern, or Pola Pengelolaan Keuangan that is applied by the local public service agency (PPK-BLUD) - must fulfill certain substantial, technical, and administrative requirements.

Out of the three aforementioned requirements, the administrative requirement is the most determinant factor in regional working units' implementation of such financial management patterns. Regional heads determine which administrative documents are to be evaluated by assessors. The assessment results are then submitted to a regional head, who will either accept or reject them. Therefore, the financial management pattern applied by local public service agency is based on the decree of the regional head rather than the local regulation. One of the administrative requirements of the financial management pattern applied by the local public service agency is the strategic business plan. According article 42, paragraph 1 of the Regulation of the Minister of Home Affairs Number 79 of 2018 , local agencies' technical implementation of such financial management patterns requires a strategic plan that has a legal basis. The subsequent paragraph states that a strategic plan accommodates the development of services, policy direction, programs, and activities as well as finance.

On January 3, 2017, the District General Hospital of Dr. (H.C.) Ir. Soekarno, owned by the Bangka Belitung Islands, was singled out for the application of the financial management pattern based on the local public service agency's scheme. Regulation of the Governor of Bangka Belitung Islands Number 71 of 2017 about the Guidelines for Business Plans and Budget and Guidelines for Strategic Business Plans applied by the District General Hospital of Dr. (H.C.) Ir. Soekarno was therefore issued to support the implementation of said financial management pattern. By then, the District General Hospital of Dr. (H.C.) Ir. Soekarno in the Bangka Belitung Islands had been in operation for only five years. Thus, the hospital was prepared to face the era of globalization with comprehensive strategic planning in order to contribute to the improvement of health services at the regional, national, and international levels.

The District General Hospital of Dr. (H.C.) Ir. Soekarno in the Bangka Belitung Islands has obtained strategic planning documents with the expirate period of 2017 to 2021. Based on the preliminary study of documents, there are some shortcomings in the implementation of this strategic plan. A strategic plan will be considered well- 
implemented if the target of hospital's services and the activities have an appropriate alignment (Bouckaert, Van den Heede, and Van de Voorde, 2018).

Any gaps in the implementation of a strategic plan also affect the achievement of national targets as listed in the Decree of the Minister of Health Number 129/Menkes/SK/II/2018 concernig the minimum service standards at hospitals. The first indicator refers to inpatient care. The net death rate (NDR) is the death rate for 48 hours per 1,000 patients treated. In other words, the NDR standard should be $<24$ per thousand, but the hospital in this study's focus had an NDR of 40.96 per thousand in 2017, meaning that the quality of service was low. However, the gross death rate (GDR) is the general death rate for every 1000 patients. An average GDR is $<45$ per thousand, but the hospital's focus was 31.78 per thousand, shows that, at least in terms of GDR, the hospital had exceeded the standard. The second national target involves the hospital's service conditions, which can be used as inputs for analyzing the hospital's environment. Service conditions are observed daily to identify inpatient care rates as one of the major hospital enterprises. The third indicator is the hospital's target to achieve better accreditation. In 2017, the passing grade of a hospital's accreditation was $62 \%$; in 2018 , it was $77 \%$. In 2018 , the hospital in question was awarded one out of five stars, indicating a quality of far below $50 \%$.

From several indicators above, many program targets had not yet been achieved, perhaps because of a lack of commitment from implementers to execute the strategic plan. Moreover, the hospital has not conducted an annual evaluation or monitoring of strategic plan's implementation process. In turn, these two problems are always repeated. Monitoring and evaluation have not been carried out to determine whether strategic planning is still appropriate for current hospital conditions, which indicates that goals for performance at the hospital have not been optimally achieved. It was proven that the targets for the period of 2017-2018 were not fulfilled in accordance with the hospital's strategic plan. The theory of Edward III, as related in Subarsono (2011), states that the implementation of a policy with the aim of achieving predetermined goals is affected by four factors: communication, resources, disposition, and bureaucratic structure. Research on the assessments of the implementation phases and evaluations of the strategic plans at 24 Iranian hospitals found that they only developed strategic plans, ignoring their implementation. Hospitals in general should regularly evaluate the progress and objectives of a strategic plan by determining what has been achieved so far (Sadeghifar et al., 2017).

From the perspective of the obstacles to the implementation of strategic plans, this research aimed to analyze the implementation process of strategic plans at the District General Hospital of Dr. (H.C.) Ir. Soekarno in the Bangka Belitung Islands. The implementation of strategic plans was evaluated in terms of communication, resources, disposition, and bureaucratic structure, all of which influence a hospital's success in achieving its goals.

\section{METHODS}

This was an explorative-descriptive study, using a qualitative method in carrying out observations and conducting in-depth interviews and document reviews (Moleong, 2007). Such a method was utilized to search for the chronology of events and the causes and effects relevant to the implementation of strategic plans at the District General Hospital of Dr. (H.C.) Ir. Soekarno Province, Bangka Belitung Province in January 2019. During the interview session, the researchers used interview guidelines to deeply probe and analyze the strategic plan implemented by the hospital from the communication, resources, dispositions, and bureaucratic structure framework based on the formulation of Edward III (1980).

Six key informants with the capacity to determine policy and formulate future strategic plans for hospitals in Bangka Belitung Province were invited to participate in the current study. They were the former director, the director, the head of administration and finance, the current head of service, the head of the outpatient nursing section, and the strategic planning team. It involved four triangulation informants, including the head of the provincial health office, the head of provincial health office, the head of the medical support unit, and the medical and nursing committee. The researchers used a purposive sampling method in order to include some informants that work closely with the implementation of strategic plans (Sugiyono, 2011).

All informants were directly involved with the implementation of strategic plans at the hospital. Data obtained through in-depth interviews, observation, and document analysis were analyzed using the Miles and Huberman model (Sugiyono, 2011). First, the data were summarized as necessary according to the study's main objectives. Next, the data were presented in narration. Finally, the researchers drew conclusions based on valid and consistent evidence. The validity of the data was determined by triangulating sources from the head of the provincial health office, the head of provincial health office, the head of the medical support unit, and the medical and nursing committee. The researchers further verified some discrepancies between different informants, considering only the consistent answers from each informant in drawing their conclusions (Sugiyono, 2011).

\section{RESULTS AND DISCUSSION}

The District General Hospital of Dr. (H.C.) Ir. Soekarno was built in 2009 using both regional and state budgets. Since July 4, 2013, it has been operating with a total of 89 beds. It was then granted operational permits based on the Regency Regulation of Bangka Regent Number 441.7/01/OP.RS/BP2TPM/IV/2015 on April 2, 2015. According to the Decree of the Governor of Bangka Belitung Province Number 188.44/1a/RSUDP/2017, it obtained the legal status to utilize the financial management pattern system and the local public service agency (Pola Pengelolaan Keuangan-Badan Layanan Umum Daerah/PPK-BLUD). To achieve this target, the hospital arranged its business strategic 
plan and budget plan. This system was expected to improve government agencies' provision of services to the community.

A strategic plan consists of vision and mission, organizational values, internal and external analysis, strategic issues, strategic maps, and key performance indicators. A budget plan, however, is an annual business budgeting plan that comprises programs, activities, minimum service standards, performance targets, and budgets from local public service agencies. The process of strategic planning includes drafting (determining vision and mission, assessing the environment, agreeing on priorities, and formulating a strategic plan), implementation, monitoring, and evaluation (Allison and Kaye, 2003). In this study, some factors that affected the strategic plan, such as communication, resources, disposition, and the security structure, were discussed further. Some obstacles to the implementation of the strategic plan were identified, such as conflicts of interest among the stakeholders, the presence of a less responsive or disobedient implementer, inadequate human resource, unilateral decision making, and non-transparent institutions. Three things are to be considered in the implementation of a strategic plan, namely: policy goals, target activities for achieving the goals, and activity outcomes. Moreover, the Edward's III theory mentions four key factors that affect the implementation of a strategic plan: communication, resources, disposition, and bureaucratic structure (Winarno, 2002).

\section{Communication}

Stakeholders will implement a strategic plan properly if they understand its assessment indicators (Nugroho, 2018). For example, communication is an indicator for successful implementation of a strategic plan among external and internal parties. To formulate a strategic plan, all stakeholders within the organization need to communicate with each other, after which the building of communication with external stakeholders can be done. Therefore, an appropriate communication model is required (Genç, 2017). Instructions for the implementation of a strategic plan must be delivered to the right person who can understand their instructions as clearly, accurately, and consistently as possible.

\section{“. . . a team from general affair and information department was assigned by the director to formulate strategic plans by adjusting their roles to their job descriptions. As a team member, I do not understand my main duties and roles in the team since they are explained. .." (Informant 3).}

The implementers of strategic plans should know how to perform in accordance with their objectives. They are also responsible for the development of the strategic plan. According to Edward III in Winarno (2002), the successful implementation of policy depends on those who decide what to do. In the drafting process, the hospital did not communicate with the provincial health office; only the drafting team was involved in that process. According to Edward III in Winarno (2002), all parties should be involved in every stage so they can review and agree upon the implementation of a policy.

\section{". . . in formulation process, there is no involvement of other related external parties (stakeholders)..." (Informant 4).}

After the strategic plan is validated, the next process is to distribute documents. According to some informants, the hospital did not conduct direct socialization after document distribution, so the team did not fully understand what the documents discussed. Inaccurate information may lead to inconsistency in formulating a strategic plan. In fact, the implementers at the hospital did not understand what was explained in the strategic plan, so they did not use the documents as a guideline for implementing the strategic plan. As a result, the targets are not achieved.

According to Agustino (2006), communication is one of the critical variables in the implementation of public policy. The implementation of public policy will be effective if decision-makers are aware of what they should do, and good communication determines how much information is understood by decision-makers (Agustino, 2006). Ideally, team members will discuss the objectives of a strategic plan for target groups so that they can prevent deviation and possible resistance from target groups (Subarsono, 2011).

The strategic planning team must have good internal communication to improve perceptions about the goals of strategic plan. Excellent two-way internal communication can encourage each member to optimize their decision-making and their coordination with stakeholders, as well as their ability to assign staff, liaise with constituents and stakeholders, and narrow down information to be discussed and evaluated by the organization (Allison and Kaye, 2003). Lack of communication within and between groups of stakeholders can result in incomprehensive environmental assessments and inconsistent strategic plans.

Furthermore, stakeholders must be involved in conducting environmental analyses for the formulation process. Excellent external communication is necessary to obtain opinions about what needs to be done and repaired, as well as possible threats that may arise (Allison and Kaye, 2003). By building effective communication, the organization takes a participatory approach to the formulation of a strategic plan. Obscure implementation of public policy is usually caused by the policy's being overly complex, the lack of consensus about the policy's objectives, problems with initiating a new policy, and a tendency to avoid the responsibilities outlined in the policy (Winarno, 2002). This will not occur in an organization if effective communication transmission, consistency in conveying information, and clarity of information are maintained. The District General Hospital of Dr. (H.C.) Ir. Soekarno has still not considered these three factors in the formulation of its strategic plans. 
". it remains inconsistence. The hospital information system has not optimally worked. Even damages often occurred. .." (Informant 2).

The implementation phase involves many actors, both from top management, internal staff, and external stakeholders. Both internal and external communication are equally important; each has its function and role. Every process in implementing strategic planning requires clear and effective communication. If the implementer has a different concept in mind, it can be detrimental to strategic planning. Therefore, the development of effective communication is particularly important.

\section{Resource}

Resources including human resources (HR), information, money, facilities and infrastructure, and authority, all of which must be managed by strategic planning resources. Health system resources are expensive and require large capital investments. Developing resources takes time and requires a large investment. Human resources are one of the most important inputs of the healthcare system, having a large impact on public health outcomes and constituting the bulk of funding in the health sector (Hashemi et al., 2018). Based on the interviews and document analysis, the District General Hospital of Dr. (H.C.) Ir. Soekarno still has problems in terms of the quantity and quality of its human resources.

During the formulation phase, the strategic planning team only consists of staff and the heads of general affairs and information departments. However, management and other stakeholders were only minimally involved. If the stakeholders in the structural position were involved in formulating the strategic plans, the decisions would have more comprehensively uncovered healthcare issues. This may have occurred because the stakeholders had high levels of authority and experience. Ideally, all management levels should conduct strategic management according to their duties and functions. Strategic management creates a pyramid hierarchy in which each level of the pyramid jointly establishes and implements strategic plans (Pearce, 2013).

Table 1. Findings and Other Related Studies.

Variables

Research Results

\section{Critical Factors based on Other Studies}

\section{Communication}

It has not gone well in terms of transmission, clarity, and consistency because of lack of socialization about strategic plan.
Lack of explanation about strategic plans to staff (Zeps and Ribickis, 2015)

Lack of communication about the strategic plan with the implementers (Radomska, 2014)

Minimal communication (Slavik in Mišanková and Kočišová, 2014)

Information inaccessible to staff (Zeps and Ribickis, 2015)

Lack of management resource (Radomska, 2014)

have not been fulfilled.

Lack of human resources (Nazemi, Asadi, and Asadi, 2015)

Authority has been implemented properly.

Disposition Poor staff motivation (Zeps and Ribickis, 2015)

The disposition from the implementers is still inadequate.

Lack of management involvement in motivating staff (Radomska, 2014)

Lack of management commitment (Radomska, 2014)

Lack of reward systems to motivate staff (Mišanková and Kočišová, 2014)

\begin{tabular}{|c|c|c|}
\hline \multirow[t]{4}{*}{$\begin{array}{l}\text { Bureaucratic } \\
\text { Structure }\end{array}$} & $\begin{array}{l}\text { Not in accordance with the type-B } \\
\text { hospital }\end{array}$ & $\begin{array}{l}\text { The non-compliance of the organizational } \\
\text { structure (Zeps and Ribickis, 2015) }\end{array}$ \\
\hline & \multirow{3}{*}{$\begin{array}{l}\text { The standard operating procedures } \\
\text { have not covered all activities. }\end{array}$} & $\begin{array}{l}\text { Lack of cross-functional } \\
\text { (Radomska, 2014) }\end{array}$ \\
\hline & & $\begin{array}{l}\text { Not supported by good organizational structure } \\
\text { (Slavik in Mišanková and Kočišová, 2014; } \\
\text { Nazemi, Asadi, and Asadi, 2015) }\end{array}$ \\
\hline & & $\begin{array}{l}\text { Non-strategic leadership (Mišanková and } \\
\text { Kočišová, 2014) }\end{array}$ \\
\hline
\end{tabular}


"There are not enough members. The competence was enough, but it still, need to be improved. The strategic planning team only consists of program staffs. Therefore, it needs more. Also, they should go on training and further education. . ." (Informant 2).

According to Allison and Kaye (2003), the strategic planning team must consist of a combination of visionaries and realists. Visionaries are people who are able to project an organization into the future and rally its members. Conversely, realists are people who guarantee the implementation of objectives and dischargement of duties. The formulation of strategic plans additionally requires the involvement of top management and staff, as well as relevant stakeholders (Allison and Kaye, 2003).

Additionally, problems with human resources were caused by the unavailability of employees. In terms of quantity, the number of human resources for formulating strategic plans was not adequate. According to the hospital's director, a lack of healthcare personnel and general technicians was also noted in other departments such as the finance and information technology departments. Previously, the hospital prioritized the recruitment of health over non-health personnel. The authority of region and state with regards to job positions makes the hospital only propose some that the government will decide later. Meanwhile, some personnel were not given compatible work.

According to Winarno (2002), one of the problems faced by the government is that an insufficient number of personnel possess management skills. Personnel who have compatible expertise often get promoted to administration, and so no longer apply their expertise. Very often, they did not need any management skills for their new positions. The lack of management skills is a big problem for the government because personnel do not tend to get exposed to professional training.

A strategic plan will be successful if the quality and quantity of human resources is sufficient. Quality in human resources relates to skill, dedication, professionalism, and competency, while quantity relates only to the numbers of human resources. Human resource has a significant influence on implementation unless the implementation of the given policy works slowly without enough reliable human resources.

Additionally, information is also an essential factor for policy implementation. Information is the second crucial source for the implementation of strategic plans. Instructions regarding the implementation of policies should be understood by implementers in order that they understand what they are doing why they are doing it. However, data regarding state regulations and programs are also important; as they are included in the information required for the implementation of strategic planning, the technical aspects of regulations and programs should be explained to the policy implementers. As stated by the informants, no information was given about how to implement a strategic plan. There were
7 No 2 December 2019

Published by Universitas Airlangga

Doi: 10.20473/jaki.v7i2.2019.123-131

no instructions for the implementation of the hospital's strategic plan. At the District General Hospital of Dr. (H.C.) Ir. Soekarno, instructions for implementing the strategic plan were issued by the strategic planning team.

“. . . using documents of strategic planning. However, there is still no special technical instructions for implementing strategic plans in the province hospital. .." (Informant 5).

During the preparation and planning phases, the District General Hospital of Dr. (H.C.) Ir. Soekarno allocated some funds to the implementation of strategic plans.

". . . there is (funding); it can still be spent properly for now. The funding source is from regional government budget. .." (Informant 1).

Good budgeting supports an effective strategic plan. Budget accuracy is especially important for strategic plans. In addition, facilities and infrastructure for the preparation and planning stages were still not available, especially because of information systems' inadequacy in supporting the rapid distribution of data and information. However, the in-depth interview results regarding the implementation stage showed that the funds, facilities, and infrastructure for health and administration services were considered sufficient.

". . . facilities and infrastructures are already sufficient to support the implementation of hospital programs. .." (Informant 1).

According to the in-depth interview, it was found that the implementers had the authority to formulate work programs and budgeting, as conveyed by the head of administration and finance. Generally, decision-makers tend to know information about various departments if they cooperate with each other. Someone should have the official authority to obligate obedience to their commands. Authority refers to the legitimacy of an implementer's application of a policy that has been stipulated (Agustino, 2006). According to Subarsono (2011), authority can determine how a program is implemented, how finance is managed, and how procurements for staff and supervisors are provided. However, the District General Hospital of Dr. (H.C.) Ir. Soekarno does have the authority to provide procurement for staff and other funds because they are organized by the regional and central government (Subarsono, 2011).

". . . the authority is given based on the main duties and functions of each position. .." (Informant 2).

\section{Disposition}

Disposition is the attitude possessed by the policy implementers; examples of this are: 
commitment, willingness, honesty, communicative skills, cleverness, and democracy (Winarno, 2002). In terms of disposition, the implementers at the District General Hospital of Dr. (H.C.) Ir. Soekarno were adequate in their preparation and formulation of strategic plans. Their behavior was supportive, and the demonstrated commitment to working together.

$$
\begin{aligned}
& \text { “. . . very supportive since strategic } \\
& \text { plans are the government policy with } \\
& \text { a good objective. .." (Informant 2). }
\end{aligned}
$$

During the preparation phase, available data and information can support the implementers. In the planning phase, they also engaged in cooperative behavior by outlining the vision and mission of the District General Hospital of Dr. (H.C.) Ir. Soekarno together and writing forms of their strategic plans. However, during the implementation phase, the implementers displayed some deficiency in their dispositions. They allowed some discrepancies into the formulation of their operational plans. Some of the operational plans were formulated without reference to the predetermined strategic targets, meaning that they were unable to optimally achieve them. This showed a lack of commitment to the strategic targets that had been decided on together.

Discrepancies also occurred because monitoring and evaluation of strategic plans was not conducted. Weak supervision of strategic plans caused these inconsistencies to recur; therefore, the hospital's targets were not achieved. Holding the same conception of a strategy that can result in the ability to compete diverse markets flexibly, positively affects company performance, invests in information technology, supports business strategies, and contributes to achieving business values (Jorfi and Jorfi, 2011)

In addition, the managerial staff at the District General Hospital of Dr. (H.C.) Ir. Soekarno were not involved in formulating strategic plans. Hierarchical, bureaucratic, and political demands were evident in every formulation of their strategic plans. If staff from across divisions lack effective communication, they will not understand as much about a strategic plan. According to Edward III in Winarno (2002), behavior and commitment are among the factors that influence the implementation of policy. If the implementers possess positive behavior and commitment, as well as adequate support, the implementation of policy will be more likely to succeed. However, if they do not possess such willingness, the policy will face rejection from others.

Negative behavior and a poor sense of commitment from implementers can be nullified by offering promotions to individuals who demonstrate a high degree of dedication toward policy implementation and public interest in their roles as policy implementers, thus lessening constraints on implementation due to rejection or ignorance. Moreover, providing incentives is an effective alternatives for improving positive behavior and commitment as it benefits the implementers. Providing incentives will encourage them to implement instructions properly out of personal interest. The manipulation of incentives has been suggested as a method of overcoming negative behavior and low levels of commitment (Agustino, 2006).

Based on the above explanation, the dispositional aspect was already satisfactory for the preparation and planning phases. However, the implementers tended to show negative dispositions during the implementation and evaluation phases, leading to the failure to achieve targets, monitoring, and evaluation due to a lack of commitment and concern.

\section{Bureaucratic Structure}

According to the in-depth interviews, the hospital has provided descriptions of primary duties and authorities for each hierarchical organization level. However, according to the hospital director, the current organizational structure still needed to be developed since it did not cover overall tasks. Several members of staff were responsible for several different tasks at once. This led to their tasks overlapping, meaning they were unable to manage other tasks that were unclearly prioritized. Moreover, the workload placed on each division was still unequal. Some departments received a heavy workload, but human resource numbers were insufficient, leading to such divisions not completing tasks optimally.

". . not yet. There are some vacant
positions even though we have
informed the National Civil Service
Agency (BKD). Moreover, as a
province hospital with type-B, its
organization structure is supposed to
be adjusted to type-B hospital. .."
(Informant 1).

To achieve its objectives, an organization must provide job divisions that are compatible with the application of strategic principles in order to facilitate the effective implementation of strategic plans, as stated by Chandler in Wahyudi (2006). According to Edward III in Winarno (2002), responsibilities and authorities in a bureaucratic structure are spread over several different departments, so they need to cooperate. Generally, the higher the level of cooperation, the better the implementation of strategic plans will be.

As the hospital director conveyed, task fragmentation often leads to an overlap of staff members' roles. Fragmentation narrows perspectives, which causes a negative impact on the implementation of strategic plans. According to Winarno (2002), one constraint on bureaucratic structures due to task fragmentation is a weakening of authority for policy implementation. Moreover, each agency or institution has limited jurisdiction with regard to other departments, so they may abandon some important tasks in favor of several other bureaucratic agendas. Furthermore, an institution or agency taking a narrow perspective may inhibit change. If missions are not able to be flexibly carried out, an organization may reject a new policy of which it may be in need. This is due to the fact that the organization tries to maintain its values (Winarno, 2002). 
According to the head of administration and finance, some standard operating procedures (SOPs) related to hospital care have been applied. Some informants felt that the SOPs for administration were not particularly important, so most SOPs were designed for health-service-related tasks. Crucially, the hospital has not provided any SOPs for the implementation of strategic plans.

\section{". . . there is no specific SOP for the implementation of strategic plans. .." (Informant 1).}

Every activity always includes some stages for its implementation whereby the given goals may be achieved. Systematic, effective, and efficient time and resources in different stages require SOPs as guidelines for implementing given tasks. The SOPs for the implementation of strategic plans should be created by experts who are able to describe the optimal methods (Amir, 2012). Moreover, roles and responsibilities in each department should be outlined in an SOP so that their tasks do not overlap.

\section{CONCLUSION}

In conclusion, the District General Hospital of Dr. (H.C.) Ir. Soekarno has not communicated the process of strategic planning well. The strategic planning team did not receive accurate and clear information due to a lack of socialization. Moreover, the quality and quantity of human resources were still lacking. Additionally, the accuracy and effectiveness of budgeting exhibited low performance. Furthermore, disposition was still lacking, and the bureaucratic structure was incompatible with a typeB hospital. There were no operational standards in place for the implementation procedures and guidelines of the strategic plan.

According to the findings of this study, the hospital needs to distribute information about its strategic plan to all stakeholders so that they can work toward its execution together. The hospital should also improve the quality of its human resources by providing training related to strategic planning skills, hiring more non-health personnel to formulate strategic plans, reactivating the hospital's information management system, reevaluating the budget plan, and employing accounting and reporting systems. Moreover, the hospital should provide rewards and incentives to improve commitment and positive behavior with regard to implementing strategic plans.

The hospital has been categorized as a typeB hospital, but applied a type-C hospital structure, which is no longer relevant. The development of its organizational structure based on a type- $\mathrm{B}$ hospital is also vital to establish the standards for operational procedures and guidelines to facilitate the implementation of strategic plans.

\section{CONFLICT OF INTEREST}

The authors state that there is no conflict of interest for this article.

\section{REFERENCES}

Agustino, L. (2006) Dasar-Dasar Kebijakan Publik. Bandung: Alfabeta.

Allison, M. and Kaye, J. (2003) Strategic Planning for Nonprofit Organizations: A Practical Guide and Workbook. 2nd edn. United States Of America: John Wiley \& Sons, Inc.

Amir, M. T. (2012) Manajemen Strategik: Konsep dan Aplikasi. Jakarta: Rajawali Press.

Assauri, S. (2017) Strategic Management: Sustainable Competitive Advantages. 2nd edn. Depok: Rajawali Pers.

Bouckaert, N., Van den Heede, K. and Van de Voorde, C. (2018) 'Improving the Forecasting of Hospital Services: A Comparison Between Projections and Actual Utilization of Hospital Services', Health Policy, 122(7), pp. 728-736. doi: 10.1016/J.HEALTHPOL.2018.05.010.

Bryson, J. M. (2016) 'Strategic Management in the Public Sector: Concepts, Schools, and Contemporary Issues by Ewan Ferlie and Edoardo Ongaro', International Public Management Journal, 19(4), pp. 596-599. doi: 10.1080/10967494.2015.1133945.

Bryson, J. M., Edwards, L. H. and Van Slyke, D. M. (2018) 'Getting Strategic about Strategic Planning Research', Public Management Review, 20(3), pp. 317-339. doi: 10.1080/14719037.2017.1285111.

Dibrell, C., Craig, J. B. and Neubaum, D. O. (2014) 'Linking the Formal Strategic Planning Process, Planning Flexibility, and Innovativeness to Firm Performance', Journal of Business Research, 67(9), pp. 2000-2007. doi: 10.1016/J.JBUSRES.2013.10.011.

Elbanna, S., Andrews, R. and Pollanen, R. (2016) 'Strategic Planning and Implementation Success in Public Service Organizations: Evidence from Canada', Public Management Review, 18(7), pp. 1017-1042. doi: 10.1080/14719037.2015.1051576.

Esfahani, P., Mosadeghrad, A. M. and Akbarisari, A. (2018) 'The Success of Strategic Planning in Health Care Organizations of Iran', International Journal of Health Care Quality Assurance, 31(6), pp. 563-574. doi: 10.1108/IJHCQA-08-2017-0145.

Ferreira, D. C. et al. (2018) 'Patients' Satisfaction: The medical Appointments Valence in Portuguese Public Hospitals', Omega, 80, pp. 58-76. doi: 10.1016/j.omega.2017.08.009.

Genç, R. (2017) 'The Importance of Communication in Sustainability \& Sustainable Strategies', in 14th Global Conference on Sustainable Manufacturing. Stellenbosch: Procedia Manufacturing, pp. 511-516.

Hashemi, H. et al. (2018) 'A Successful Implementation of an Idea to a Nationally Approved Plan: Analyzing Iran's National Health Roadmap Using the Kingdon Model of Policymaking', Medical Journal of the Islamic Republic of Iran, 32(46), pp. 1-6. doi: 10.14196/mjiri.32.46.

Helmig, B., Hinz, V. and Ingerfurth, S. (2014) 'Extending Miles \& Snow's Strategy Choice Typology to the German Hospital Sector', Health Policy, 118(3), pp. 363-376. doi: 
10.1016/J.HEALTHPOL.2014.06.006.

Höglund, L. et al. (2018) 'Strategic Management in the Public Sector: How Tools Enable and Constrain Strategy Making', International Public Management Journal, 21(5), pp. 822849. doi: 10.1080/10967494.2018.1427161.

Jamshidi, L. et al. (2017) 'Equity in the Quality of Hospital Services in Iran', Medical Journal of the Islamic Republic of Iran, 31(109), pp. 1-5. doi: $10.14196 /$ mjiri.31.109.

Jorfi, H. and Jorfi, S. (2011) 'Strategic Operations Management: Investigating the Factors Impacting Communication Effectiveness and Job Satisfaction', Procedia - Social and Behavioral Sciences, 24, pp. 1596-1605. doi: 10.1016/J.SBSPRO.2011.09.003.

Klag, M. and Langley, A. (2014) 'Critical Junctures in Strategic Planning: Understanding Failure to Enable Success', Organizational Dynamics, 43(4), pp. 274-283. doi: 10.1016/J.ORGDYN.2014.09.004

Mišanková, M. and Kočišová, K. (2014) 'Strategic Implementation as A Part of Strategic Management', Procedia - Social and Behavioral Sciences, 110, pp. 861-870. doi: 10.1016/j.sbspro.2013.12.931.

Moleong, L. J. (2007) Metodologi Penelitian Kuantitaif. Revisi. Bandung: PT. Remaja Rosdakarya.

Nazemi, S., Asadi, S. T. and Asadi, S. T. (2015) 'Barriers to Strategic Planning Implementation; Case of: Mashhad Electricity Distribution Company', Procedia - Social and Behavioral Sciences, 207, pp. 2-9. doi: 10.1016/j.sbspro.2015.10.142.

Pearce, J. A. (2013) Manajemen Strategis. 12th edn. Jakarta: Salemba Empat.

Peixoto, M. G. M., Musetti, M. A. and Mendonça, M. C. A. (2018) 'Multivariate Analysis Techniques Applied for the Performance Measurement of Federal University Hospitals of Brazil', Computers and Industrial Engineering, 126, pp. 16-29. doi: 10.1016/j.cie.2018.09.020.

Pollanen, R. et al. (2017) 'Relationships between Strategic Performance Measures, Strategic Decision-Making, and Organizational Performance: Empirical Evidence from Canadian Public Organizations', Public Management Review, 19(5), pp. 725-746. doi: 10.1080/14719037.2016.1203013.

Radomska, J. (2014) 'Linking the Main Obstacles to the Strategy Implementation with the Company's Performance', Procedia - Social and Behavioral Sciences, 150, pp. 263-270. doi: 10.1016/J.SBSPRO.2014.09.054.

Rosenberg Hansen, J. and Ferlie, E. (2016) 'Applying Strategic Management Theories in Public Sector Organizations: Developing a Typology', Public Management Review, 18(1), pp. 1-19. doi: 10.1080/14719037.2014.957339.

Sadeghifar, J. et al. (2017) 'An Assessment of Implementation and Evaluation Phases of Strategic Plans in Iranian Hospitals', SAGE Open Medicine, 5, pp. 1-6. doi: 10.1177/2050312117736227.

Suarez, E., Calvo-Mora, A. and Roldán, J. L. (2016)
'The Role of Strategic Planning in Excellence Management Systems', European Journal of Operational Research, 248(2), pp. 532-542. doi: 10.1016/j.ejor.2015.07.008.

Subarsono, A. B. (2011) Analisis Kebijakan Publik, Konsep, Teori, dan Aplikasi. Yogyakarta: Pustaka Pelajar.

Sugiyono (2011) Metode Penelitian Pendidikan Pendekatan Kuantitatif, Kualitatif, dan R\&D. Bandung: Alfabeta.

Wahyudi, A. S. (1996) Manajemen Strategik: Pengantar Proses Berfikir Strategik. Jakarta: Binarupa Aksara.

Winarno, B. (2002) Teori dan Proses Kebijakan Publik. Yogyakarta: Media Pressindo.

Zeps, A. and Ribickis, L. (2015) 'Strategy Development and Implementation - Process and Factors Influencing the Result: Case Study of Latvian Organizations', Procedia Social and Behavioral Sciences, 213, pp. 931-937.

doi: 